\title{
PRZEMYSŁAW KACZMAREK
}

ORCID: 0000-0002-3436-4043

Uniwersytet Wrocławski

\section{POLITYCZNOŚĆ W PRAKTYCE ORZECZNICZEJ - W ROZMOWACH O PAŃSTWIE PRAWA Z EWĄ ŁĘTOWSKĄ, ANDRZEJEM ZOLLEM, ANDRZEJEM WRÓBLEM*}

\begin{abstract}
Abstrakt: W prezentowanym artykule starałem się wykazać obecność tematyki polityczności w polskiej debacie o praktyce orzeczniczej. Realizując ten cel, najpierw przedmiotem uwagi czynię rozmowy z Ewą Łętowską, Andrzejem Zollem i Andrzejem Wróblem, które przeprowadził Krzysztof Sobczak. Następnie odpowiadam na pytanie, jak rozumiana polityczność wyłania się z tych rozmów. Wypełniając to zadanie, odwołuję się do słownika pojęć zaproponowanego przez Michaela Oakeshotta.
\end{abstract}

Słowa kluczowe: polityczność, rola sędziego, rządy prawa, praktyka sądowa

\section{WPROWADZENIE. POLITYKA WIARY CZY POLITYKA SCEPTYCYZMU? ${ }^{1}$}

Jednym z celów niniejszego artykułu jest wykazanie, że tematyka polityczności w praktyce orzeczniczej jest obecna w polskiej debacie o państwie prawa ${ }^{2}$. Ze względu na ramy artykułu, realizując to zadanie, przedmiotem badań uczynię tylko fragment tej debaty, limitowany rozmowami z Ewą Łętowską, Andrzejem Zollem i Andrzejem Wróblem, które przeprowadził Krzysztof Sobczak w ramach serii wydawniczej poświęconej polskiej transformacji ustrojowej po 1989 roku $^{3}$.

* Artykuł powstał w ramach badań nad projektem Narodowego Centrum Nauki nr 2016/21/B/ HS5/00164 pod tytułem Idea apolityczności prawoznawstwa wobec krytyki nowoczesnej filozofii wiedzy.

1 Za uwagi językowe na wstępnym etapie przygotowania artykułu dziękuję mgr Hannie Włoch.

2 Por. R. Mańko, Nauki prawne wobec problemu polityczności: zagadnienia wybrane z perspektywy jurysprudencji krytycznej, „Archiwum z Filozofii Prawa i Filozofii Społecznej” 2018, nr 3, s. 39 i 46-48; M. Stambulski, Polityczność jako etyka polityczna prawa, [w:] Aksjologiczny wymiar prawa, red. M. Dudek, M. Stępień, Kraków 2015, s. 97, 104.

3 E. Łętowska, K. Sobczak, Rzeźbienie państwa prawa. 20 lat później. Ewa Łętowska w rozmowie z Krzysztofem Sobczakiem, Warszawa 2012; K. Sobczak, A. Zoll, Państwo prawa jeszcze w bu- 
Wybór przedmiotu badań uważam za uzasadniony, po pierwsze, dlatego że wspomniane rozmowy można traktować jako zwarty i spójny materiał badawczy. Po drugie, wymienione osoby są ważnymi uczestnikami procesu budowania państwa prawa w Polsce po 1989 roku.

W celu wyjaśnienia kwestii terminologicznych odwołajmy się najpierw do ustaleń Rafała Mańki, który przybliża znaczenie trzech pojęć: polityczności, polityki partyjnej i polityk publicznych ${ }^{4}$.

Pojęcie polityczności przedstawiane jest w świetle antagonizmu jako właściwości społecznej. Sytuację antagonizmu można rozumieć jako konflikt między wartościami, założeniami światopoglądowymi. Zdaniem R. Mańki: „Tak zdefiniowana polityczność oczywiście przejawia się często w sporach sądowych; im bardziej dane społeczeństwo jest zjurydyzowane, tym częściej spory, nie tylko ekonomiczne, ale i kulturowe, będą rozstrzygane przez sądy"5. Wyrazem tak rozumianej jurydyczności, według tego badacza, jest polityczność orzekania. Jest ona przedstawiana przez autora w świetle dwóch właściwości: decyzyjności i konfliktu między określonymi dobrami ${ }^{6}$. Decyzyjność podkreśla sytuację dyskrecjonalności, w jakiej orzeka interpretator. Z kolei sytuacja konfliktu eksponuje fakt napięcia między racjami działania.

Kolejne pojęcie wymagające wyjaśnienia to polityka. Jest ona rozumiana jako działanie związane „z dążeniem do uzyskania i utrzymania władzy politycznej”’”. Tak postrzegana polityka przedmiotem badań czyni działalność zwłaszcza partii politycznych i dlatego można ją określić mianem polityki partyjnej ${ }^{8}$.

Ostatnie z wymienionych pojęć — polityki publiczne - R. Mańko wyróżnia ze względu na obszary aktywności państwa czy też organizacji międzynarodowych. W tym kontekście można mówić, jak odnotowuje autor, na przykład o polityce obronnej czy zagranicznej.

dowie. Andrzej Zoll w rozmowie z Krzysztofem Sobczakiem, Warszawa 2013; K. Sobczak, A. Wróbel, Warto chronić państwo prawa. Andrzej Wróbel w rozmowie z Krzysztofem Sobczakiem, Warszawa 2017. Należy odnotować, że wskazana seria wydawnicza obejmuje również rozmowy z Andrzejem Rzeplińskim, Jackiem Gudowskim i Małgorzatą Gersdorf. Zob. A. Rzepliński, K. Sobczak, Stużąc rządom dobrego prawa. Andrzej Rzepliński w rozmowie z Krzysztofem Sobczakiem, Warszawa 2015; J. Gudowski, K. Sobczak, Państwo prawa to niezależne sądy. Jacek Gudowski w rozmowie z Krzysztofem Sobczakiem, Warszawa 2018; M. Gersdorf, K. Sobczak, Czasem trzeba powiedzieć „,nie” - Matgorzata Gersdorf w rozmowie z Krzysztofem Sobczakiem o swojej walce o niezależne sady, Warszawa 2020.

${ }^{4}$ R. Mańko, op. cit., s. 39 n.; idem, W stronę krytycznej filozofii orzekania. Polityczność, etyka, legitymizacja, Łódź 2018, rozdz. 3. Zob. także M. Stambulski, Polityczność w polskiej analitycznej teorii prawa. Zarys problematyki, „Archiwum z Filozofii Prawa i Filozofii Społecznej” 2018, nr 3, s. 72.

5 R. Mańko, Nauki prawne..., s. 40.

${ }^{6}$ R. Mańko, W stronę krytycznej filozofii..., s. 154 n.

7 R. Mańko, Nauki prawne..., s. 41.

${ }^{8}$ Zob. C. Schmitt, Pojęcie polityczności, [w:] idem, Teologia polityczna i inne pisma, przeł. M.A. Cichocki, Kraków 2000, s. 203. 
Wydaje się, że pierwsze dwa z wyróżnionych ujęć można odnieść do weberowskiego pojęcia polityki. Przypomnijmy, że niemiecki socjolog pisze o polityce jako działaniu:

1. zmierzającym do udziału we władzy między organami władzy publicznej;

2. celowym, ukierunkowanym na podejmowanie decyzji w sytuacji sprzecznych interesów9.

Andrzej Bator, czyniąc weberowskie ujęcia przedmiotem badań, wskazuje, że ilustrują one dwie perspektywy mówienia o polityce: pragmatyczną i apragmatyczną ${ }^{10}$. W pierwszej z nich, jak odnotowuje wrocławski teoretyk, stawiamy pytania „kto ma władzę?”, ,jak jest ona sprawowana?”. Z kolei w drugiej perspektywie — apragmatycznej - polityka ukierunkowana jest na odpowiedź na pytanie: „do realizacji jakich wartości sprawowanie władzy ma służyć?"11.

Ostatnie z wymienionych pytań podejmuje Michael Oakeshott w pracy Polityka wiary i polityka sceptycyzmu ${ }^{12}$. Autor przedstawia w niej dwie wizje polityki, które określa mianem polityki wiary i polityki sceptycyzmu ${ }^{13}$. Są to modele ilustrujące dwie skrajne wizje rządzenia.

Polityka wiary opiera się na założeniu, że celem rządzenia jest dążenie do doskonałości człowieka jako członka społeczeństwa ${ }^{14}$. Do realizacji tego celu konieczna jest władza rządu, który - poprzez prawo stanowione - kształtuje drogę do osiągnięcia doskonałości. W wizji tej jedną z funkcji rządzenia jest wychowywanie człowieka ${ }^{15}$. $Z$ tego powodu władza rości sobie prawo do regulowania różnych sfer aktywności jednostki ${ }^{16}$. Pojęcia na linii państwo-obywatel, jakie oferuje polityka wiary, to posłuszeństwo, bezpieczeństwo ${ }^{17}$. Jak zauważa M. Oakeshott: ,zgodnie z tym rozumieniem polityki nie będzie się uważać instytucji rządowych za ośrodki załatwiania spraw lub podejmowania określonego rodzaju decyzji, lecz za ośrodki dążenia do »prawdy«, rugowania »błędu« i zapewnia-

9 M. Weber, Gospodarka i społeczeństwo. Zarys socjologii rozumiejącej, przeł. i wstęp D. Lachowska, Warszawa 2002, s. 17 n.

10 A. Bator, Polityczne interpretacje analitycznej teorii prawa, [w:] Integracja zewnętrzna $i$ wewnętrzna nauk prawnych. Cz. 1, red. M. Zirk-Sadowski, B. Wojciechowski, T. Bekrycht, Łódź 2014, s. 14.

11 Ibidem.

12 M. Oakeshott, Polityka wiary i polityka sceptycyzmu, przeł. M. Szczubiałka, red. T. Fuller, Warszawa 2019, s. 35-36.

13 Syntetycznie przedstawia te wizje Paweł Śpiewak, $W$ stronę wspólnego dobra, Warszawa 1998, s. 186 n.

14 M. Oakeshott, op. cit., s. 72.

15 F.G. Wolmarans, A 'conversation' concerning political understanding: Bacon contra Augustine or the 'politics of faith' contra the 'politics of scepticism', „Politikon: South African Journal of Political Studies" 29, 2002, s. 73-74.

16 M. Oakeshott, op. cit., s. 74 i 82.

17 M. Polakowski, Sceptycyzm w polityce. Studium myśli politycznej Michaela Oakeshota, Płock 2017, s. 201. 
nia zwycięstwa »prawdzie«"18. Z tego też względu, jak zauważa Paweł Śpiewak, rząd, dążąc do realizacji określonych idei, może modyfikować prawo formalne ${ }^{19}$.

Za odmienną wizją rządzenia opowiada się polityka sceptycyzmu ${ }^{20}$. Jej celem nie jest dążenie do doskonałości człowieka. Co więcej, takie tendencje uważa się za niewłaściwe, albowiem zakłada stawianie rządu w pozycji sędziego moralności, który za pomocą prawa rozstrzyga o etyczności działania w różnych sferach aktywności człowieka. Wzmacniając ten zarzut, podkreśla się, że rolą władz publicznych nie jest narzucanie społeczeństwu jednej doktryny moralności ${ }^{21}$. $\mathrm{Z}$ tego powodu polityce sceptycyzmu bliższa jest zasada trójpodziału władzy ${ }^{22}$. Uzasadniając jej wagę, można wskazać na argument społeczny i instytucjonalny. Argument społeczny broni stanowiska, że trójpodział władzy służy ochronie obywateli przed arbitralnością władz publicznych ${ }^{23}$. Znaczenie tego argumentu można przedstawić, odwołując się do myśli Marcina Matczaka o trzech racjach ${ }^{24}$. Zakłada ona, że w przestrzeni publicznej mamy najczęściej wyrażane dwie podstawowe linie argumentacyjne. Pierwsza z nich formułowana jest przez większość parlamentarną. Można przyjąć, że racja ta przedstawia stanowisko znacznej części społeczeństwa, zwłaszcza tej, która uczestniczy w wyborach parlamentarnych. Druga racja głoszona jest przez świat korporacji, firmy międzynarodowe, które bronią przede wszystkim interesu społeczno-ekonomicznego. Oprócz tych dwóch racji powinno się uwzględniać również trzecią — aby zapobiec tyranii większości i silniejszego. Takie zadanie stoi przed sądami, które w tym celu powinny realizować prawa jednostki zapisane w konstytucji, traktatach międzynarodowych oraz prawie Unii Europejskiej ${ }^{25}$. Z kolei argument instytucjonalny podkreśla, że dla sprawnego działania instytucji ważne jest zachowanie zasady podejrzliwości. Podejrzliwość ta odnosi się do każdej z władz publicznych, dlatego lepsze są roz-

18 M. Oakeshott, op. cit., s. 79-80.

19 P. Śpiewak, Granice polityki, [w:] M. Oakeshott, Wieża Babel i inne eseje, przeł. A. Lipszyc, Ł. Sommer, M. Szczubiałka, Warszawa 1999, s. 16.

${ }^{20}$ M. Oakeshott, Polityka wiary..., s. 85.

${ }^{21}$ Michael Oakeshott pisze: „Rząd nie jest tu powołany do roli architekta doskonałego sposobu życia ani (jak to ujmuje polityka wiary) lepszego sposobu życia, ani nawet (jak się okazuje) żadnego w ogóle sposobu życia" —ibidem, s. 88. Zob. także ibidem, s. 95.

22 Syntetycznie M. Oakeshott, Losy sceptycyzmu. Rozproszenie władzy a tradycje angielskiej polityki, przeł. S. Stecko, „Nowa Res Publica” 2002, nr 9, s. 110.

${ }^{23}$ M. Oakeshott, Polityka wiary..., s. 186 n. Zob. także P. Śpiewak, W stronę wspólnego dobra..., s. 187.

${ }^{24}$ Mam nadzieję, że nie dokonałem zniekształcenia myśli Marcina Matczaka, przedstawionej — jeśli dobrze pamiętam — na jednym z seminariów wrocławskiej Katedry Teorii i Filozofii Prawa Uniwersytetu Wrocławskiego.

25 Podobną myśl o roli sędziów w społeczeństwie formułuje Ewa Łętowska: „mieć niezawisłe sądy - to się opłaca. Nie samym sędziom. Społeczeństwu. Bo bez niezawisłych sędziów nie ma państwa prawa, tak jak nie ma demokratycznego społeczeństwa bez wolnych mediów" - eadem, Dekalog sędziego. Dwadzieścia lat później, [w:] Konstytucja, praworządność, władza sądownicza. Aktualne problemy trzeciej władzy w Polsce, red. Ł. Bojarski et al., Warszawa 2019, s. 251. 
wiązania, które rozpraszają władzę na różne ośrodki ${ }^{26}$. $\mathrm{Z}$ tego względu tak dużą wagę przywiązuje się do formalnych kotwic w postaci rządów prawa, trójpodziału władzy ${ }^{27}$. Z perspektywy polityki wiary konstrukcje te bywają poddawane krytyce. Jej wyrazem jest kwestionowanie niezależności sądownictwa jako władzy, której działalność nie podlega kontroli pozostałych dwóch ośrodków władzy, to jest wykonawczej i ustawodawczej ${ }^{28}$. Dodajmy jeszcze, że politykę sceptycyzmu od polityki wiary różni również wątpliwość wobec jurydyzacji kolejnych sfer życia codziennego, dla której roszczenie do regulacji jest istotne ${ }^{29}$.

W polityce sceptycyzmu wartością jest sytuacja napięcia. Można ją odnieść nie tylko do konfliktu między ośrodkami władzy, ale i działalności orzeczniczej. W praktyce sądowej ważne miejsce przypisuje się precedensom (kulturze sędziowskiej) przy jednoczesnym zachowaniu podmiotowej sprawczości ${ }^{30}$. Wskazane napięcie między tym, co intersubiektywne, a tym, co indywidualne, widoczne jest także w wizji rządów prawa, za jaką opowiada się polityka sceptycyzmu ${ }^{31}$. Z jednej strony, przedstawia się je jako formalistyczny sposób zarządzania, który osłabia (potencjalną) arbitralność osób sprawujących władzę. Z drugiej jednak strony, podkreśla się konieczność zachowania krytycyzmu wobec zastanych standardów jako tych, które nieożywiane w działaniu mogą być źródłem złych praktyk ${ }^{32}$.

Odwołując się do proponowanej przez M. Oakeshotta opozycji, zakładam, że w polskiej debacie o państwie prawa można odnaleźć stanowiska i idee, które rekomendują model polityki sceptycyzmu. Poddanie weryfikacji tej hipotezy jest drugim, po dokumentacji obecności tematyki polityczności w polskiej debacie o państwie prawa, celem niniejszego artykułu. Obie te hipotezy będą weryfikowane na przykładzie materiału badawczego w postaci rozmów o państwie prawa z Ewą Łętowską, Andrzejem Zollem i Andrzejem Wróblem. Dla jasności prowadzonego wywodu chciałbym zaznaczyć, że weryfikacja postawionych hipotez jest zadaniem o charakterze interpretacyjnym ${ }^{33}$. Jego celem jest próba odniesienia wypowiedzi wymienionych prawników do pojęcia polityczności, którym autorzy nie zawsze posługują się w sposób bezpośredni.

26 M. Oakeshott, Polityka wiary..., s. 187.

27 Pojęcia kotwicy używam w znaczeniu bezpiecznika, gwarancji. Zob. P. van Lochem, Legislation against the rule of law - an introduction, „The Theory and Practice of Legislation” 5, 2017, s. 99.

28 M. Oakeshott, Polityka wiary..., s. 186.

29 M. Polakowski, op. cit., s. 201-205.

30 M. Oakeshott, Polityka wiary..., s. 98.

31 Ibidem, s. 190.

32 Praktyki te przedstawia Adam Shinar, One rule to rule them all? Rules of law against the rule of law, „The Theory and Practice of Legislation” 5, 2017, s. $157 \mathrm{n}$.

33 Mam nadzieję, że wykonując to zadanie, nie dokonałem zniekształcenia myśli Ewy Łętowskiej, Andrzeja Zolla i Andrzeja Wróbla. 


\section{POLITYCZNOŚĆ W PRAKTYCE ORZECZNICZEJ W ROZMOWIE Z EWĄ ŁĘTOWSKĄ}

Dla Ewy Łętowskiej ważnym składnikiem urzeczywistniania się idei państwa prawa jest zasada trójpodziału władzy ${ }^{34}$. Postulatowi wzajemnego równoważenia się władzy sądowniczej, ustawodawczej i wykonawczej badaczka przypisuje zdecydowanie pozytywny wydźwięk. Przedstawiając wartość tej zasady, autorka wskazuje na rozmaite aspekty:

Podział władz jest mądrą instytucją także dlatego, że wybierana władza ustawodawcza działa od wyborów do wyborów. Z kolei władza wykonawcza funkcjonuje według swoich reguł i ma różnego typu uwarunkowania lokalne, personalne i hierarchiczne, a to ją pcha w uwikłania interesów. W tym systemie chodzi o to, żeby minimalizować skutki uwikłań, a czasem patologii. Gdy jest „trzecie oko”, włącza się inny, zewnętrzny czynnik — są nim sądy. Prawo do sądu jest więc rodzajem bezpiecznika chroniącego przed dewiacjami pierwszej i drugiej władzy ${ }^{35}$.

Z przytoczonego cytatu można zrekonstruować różne argumenty uzasadniające władzę sądowniczą. Jednym z nich jest ten podkreślający, że trójpodział władzy to przynajmniej formalne zabezpieczenie przed pokusą nadużywania władzy w sytuacji braku kontroli nad nią. Wskazany rozdział jest formalną kotwicą, która ma zapobiec nie tylko utracie atrybutu niezależności, ale i w aspekcie podmiotowym niezawisłości sędziowskiej. Jeśli zatem przyjmujemy, że prawo jest obecnie ważnym systemem normatywnym, który ma potencjał do regulowania relacji międzyludzkich w społeczeństwie, to uzasadniona staje się ochrona tego systemu. Jest tak również z tego powodu, że trójpodział władzy zapewnia realizację prawa do sądu rozumianego jako możliwość odwołania się przez obywatela od decyzji różnych ośrodków decyzyjnych w państwie ${ }^{36}$.

Wyłaniające się z zasady trójpodziału władzy napięcie między władzą sądowniczą a wykonawczą i ustawodawczą odsłania problem polityczności w praktyce orzeczniczej. Dla porządku odnotujmy jednak, że z wypowiedzi Ewy Łętowskiej można zrekonstruować dwa ujęcia polityczności. Pierwsze z nich odnosi się do konfliktu między wartościami w sferze publicznej. Dlatego spór o wartości jest sytuacją, w której przychodzi rozstrzygać sędziemu. Z kolei drugie ujęcie dotyczy zaangażowania określonych środowisk w lobbowaniu za danym rozwiązaniem. W takim wypadku prawniczka pisze nie tyle o sile argumentu, ile raczej argumencie siły ${ }^{37}$.

Sytuację sporu o wartości, z którą musi zmierzyć się sędzia, autorka przedstawia jako właściwość pożądaną praktyki orzeczniczej. Zważywszy na stan faktyczny, a także dobra, między którymi tworzy się sytuacja konfliktu, należy podej-

\footnotetext{
34 E. Łętowska, K. Sobczak, op. cit., s. 141.

35 Ibidem, s. 142.

36 Ibidem, s. 142-143.

37 Ibidem, s. 24.
} 
mować rozstrzygnięcie, kierując się zasadą proporcjonalności. Sytuacja wyboru, przed którym stoi sędzia, i konieczność podjęcia decyzji mogą budzić niepokój38. Może on w konsekwencji prowadzić do wyboru postawy Piłata ${ }^{39}$. Określeniem tym możemy posługiwać się na oznaczenie faktycznego procesu myślenia Poncjusza Piłata, lecz także jako figury, której używa się na oznaczenie nieumiejętności osądu i w konsekwencji dopasowania się do obowiązującego wzorca postępowania $^{40}$. Drugie z wymienionych ujęć można, moim zdaniem, przypisać rozważaniom E. Łętowskiej na temat postawy Piłata. Wśród przyczyn wyboru takiego podejścia autorka wymienia brak chęci, odwagi, umiejętności albo wiedzy prawniczej. Podstawowe jest jednak niezaangażowanie aksjologiczne ${ }^{41}$. Przekłada się ono na dwa problemy, ogniskujące się wokół odpowiedniego poziomu: (1) wątpliwości interpretacyjnych - skali tych wątpliwości, (2) poczucia odpowiedzialności za podejmowaną sprawę, a szerzej — za obraz praktyki orzeczniczej.

Z kolei polityczność rozumianą jako próbę ingerowania przez ważnych aktorów życia publicznego w treść rozstrzygnięcia E. Łętowska uznaje za sytuację niewłaściwą. Przedstawiając ją, omawia przypadek wprowadzenia religii do szkół w roku szkolnym 1990/1991 oraz działalność Komisji Majątkowej.

Autorka, omawiając pierwszą z wymienionych spraw, odnotowuje, że w 1990 roku nie było konstytucyjnej podstawy do wprowadzenia religii do szkół, równolegle z nauką etyki ${ }^{42}$. Zabiegu tego dokonano za pomocą instrukcji wydanej 3 sierpnia 1990 przez Ministra Edukacji Narodowej, to jest aktem kierownictwa wewnętrznego, a nie ustawy. Tak tę sytuację ocenia E. Łętowska:

[religia do szkół] została wprowadzona aktem rangi instrukcji, nieprawidłowym z punktu widzenia standardów państwa prawa. Dlatego, będąc wówczas Rzecznikiem Praw Obywatelskich, wniosłam sprawę do Trybunału Konstytucyjnego ${ }^{43}$.

Za wprowadzeniem religii do szkół, począwszy od roku szkolnego 19901991, mocno optowała strona kościelna, której racje starano się uwzględniać. Dobrze tę kwestię dokumentuje przywoływana przez E. Łętowską rozmowa z Antonim Macierewiczem: ,»Oczywiście od strony czysto prawnej ma pani rację, ale przecież nie o to prawo chodzi«. No więc pytam: a o co ma chodzić?"44.

Drugiego przykładu polityczności dostarcza działalność Komisji Majątkowej Kościoła Katolickiego. Zdaniem E. Łętowskiej za jej powołaniem przemawiały dwa argumenty. Pierwszy odwoływał się do sprawiedliwości transformacyjnej45.

38 Ibidem, s. 81-82.

39 Ewa Łętowska pisze o postawie Piłata w ibidem, s. 81-82, 89-90, 245, 297.

40 Zob. H.G. Gadamer, Cóż to jest prawda?, [w:] idem, Rozum, słowo, dzieje. Szkice wybrane, wyb., oprac. i wstęp K. Michalski, przeł. M. Łukasiewicz, K. Michalski, Warszawa 1979, s. 32.

41 E. Łętowska, K. Sobczak, op. cit., s. 116, 133.

42 Ibidem, s. 21.

43 Ibidem, s. 23.

44 Ibidem, s. 61.

45 Ibidem, s. 49. 
Jej podstaw można upatrywać w dążeniu do oddania Kościołowi majątku zagarniętego przez komunistyczne władze po II wojnie światowej. Drugiego argumentu autorka doszukuje się z kolei w rozliczeniu się nowej władzy solidarnościowej z władzami kościelnymi. Na jego przykładzie E. Łętowska pisze o rachunku: „Za to, że był — to jego niewątpliwa historyczna zasługa — ośrodkiem oporu przeciwko komunistycznej władzy, że pomagał opozycji walczącej z tamtym ustrojem" 46 . $\mathrm{O}$ ile pierwszy z wymienionych argumentów ma charakter prawno-ustrojowy, o tyle drugi ma status polityczny. Badaczka, dokumentując ten aspekt, wskazuje na genezę powstania ustawy regulującej działalność Komisji Majątkowej:

Pamiętam zdanie z pisma biskupa Alojzego Orszulika, który podczas postępowania przed Trybunałem Konstytucyjnym w sprawie W 11/91 [...] lansował pogląd, że ustawa z 1989 roku nie tylko tworzy Massnahmegesetz w ramach systemu prawa, na który składa się ustawa zwykła, ale jest wyjątkiem wobec Konstytucji, a zatem jej nie podlega ${ }^{47}$.

O tak rozumianej polityczności w praktyce orzeczniczej jako uwzględnianiu interesów określonych grup społecznych zdaje się mówić E. Łętowska, również kiedy podaje w wątpliwość orzeczenia sądów powszechnych, odmawiające wszczęcia postępowania odwoławczego od decyzji Komisji Majątkowej ${ }^{48}$. W ustawie, która stanowiła podstawę działalności Komisji, była mowa o braku odwołania od decyzji Komisji na drodze administracyjnej ${ }^{49}$. Jak zauważa ceniona prawniczka, czym innym jest nieuwzględnienie odwołań na linii Skarb Państwastrona kościelna, a czym innym uniemożliwianie wszczęcia postępowań sądowych przez strony trzecie, które zostały dotknięte skutkami decyzji Komisji.

$\mathrm{Z}$ ustaleń E. Łętowskiej można wyprowadzić dwa oblicza polityczności. O ile proces podejmowania decyzji w sytuacji konfliktu wartości autorka przedstawia jako pożądaną właściwość praktyki orzeczniczej, o tyle drugą z sytuacji, sprowadzającą polityczność do argumentu siły, można nazwać bolączką wymiaru sprawiedliwości.

\section{POLITYCZNOŚĆ W PRAKTYCE ORZECZNICZEJ W ROZMOWIE Z ANDRZEJEM ZOLLEM}

W rozważaniach Andrzeja Zolla ważne miejsce zajmuje zasada trójpodziału władzy. Jej celem jest doprowadzenie do sytuacji równoważenia się władzy między poszczególnymi ośrodkami stanowienia i stosowania prawa. Warto odnotować, że pojęcie władzy związane jest z kwestią polityczności ${ }^{50}$. Mając to na uwadze, moż-

46 Ibidem.

47 Ibidem, s. 59.

48 Ibidem, s. 51.

49 Ustawa z dnia 17 maja 1989 roku o stosunku Państwa do Kościoła Katolickiego w Rzeczypospolitej Polskiej, Dz.U. Nr 29, poz. 154.

${ }^{50}$ K. Sobczak, A. Zoll, op. cit., s. 145. 
na wypowiedzi krakowskiego badacza próbować przyporządkować do dwóch ujęć polityczności. Pierwsze z nich dotyczy związków polityki z władzą sędziowską. W tym ujęciu mowa o polityczności na oznaczenie (potencjalnego) wpływu czy też presji, jaką może wywierać zwłaszcza władza wykonawcza na działalność sędziów. Tak rozumiana polityczność ,jest pewnym dążeniem grupy reprezentującej określoną opcję polityczną" ${ }^{51}$ do wywierania wpływu na praktykę orzecznicząą Przykładem wpływu świata polityki na wymiar sprawiedliwości może być wybór sędziów do Trybunału Konstytucyjnego. Jak jednak zauważa A. Zoll, mimo wyboru, który jest dokonywany przez polityków, z upływem czasu można zaobserwować proces odchodzenia od etykiet partyjnych. Zdaniem autora jest to efekt kultury sędziowskiej, która ma wpływ na praktykę orzeczniczą Trybunału Konstytucyjnego ${ }^{53}$.

Innym aspektem pragmatycznie rozumianej polityczności - jako walki o władzę - jest spór między władzą ustawodawczą a sądowniczą w zakresie prawomocności orzeczeń Trybunału Konstytucyjnego. Warto przypomnieć, że do 1997 roku, to jest uchwalenia nowej konstytucji, orzeczenia Trybunału Konstytucyjnego mogły być odrzucane przez Sejm. Jak zauważa A. Zoll: „To ciekawe, że zmienił się ustrój, a nowa władza też bardzo broniła tego swojego przywileju w stosunku do Trybunału Konstytucyjnego" 54 .

Drugie z ujęć polityczności dotyczy uwzględniania określonych wartości, ważenia racji w procesie decyzyjnym. W tej perspektywie polityczność praktyki orzeczniczej jest konsekwencją rozstrzygania spraw o dużym ładunku aksjologicznym ${ }^{55}$. Przykładem tak rozumianego zaangażowania politycznego jest wyrok Trybunału Konstytucyjnego w sprawie emerytur specjalnych nadawanych w okresie PRL. Emerytury te zostały zniesione ustawą, która została zaskarżona przez prezydenta Wojciecha Jaruzelskiego do Trybunału Konstytucyjnego. Podnoszonym w tym zakresie argumentem była ochrona praw nabytych. Jak odnotowuje A. Zoll, sędzia Trybunału Konstytucyjnego w tym czasie:

Trybunał stanął na stanowisku, że ochronie podlegają tylko prawa słusznie nabyte, a to może podlegać wartościowaniu. Stwierdziliśmy, że nie można uznać, iż każde prawo nabyte podlega ochronie, że w takich przypadkach musi być uwzględniana pewna podstawa aksjologiczna do oceny takiego prawa, które daje komuś jakieś przywileje. W każdym razie uznaliśmy, że ustawa, która zniosła PRL-owskie emerytury specjalne, była zgodna z Konstytucją ${ }^{56}$.

51 Ibidem, s. 164.

52 Ibidem, s. 36, 37 i 104.

53 Ibidem, s. 134. W innym miejscu Andrzej Zoll zauważa: „Był czas, gdy otwartym tekstem mówiono, ilu to my już mamy swoich sędziów w Trybunale Konstytucyjnym. To była zapowiedź, że ta partia chce opanować wszystko. Jeżeli Trybunał ma być opanowany przez jedną siłę polityczną, to do czego coś takiego prowadzi? Może lepiej całkiem zrezygnować z takiej instytucji?" — ibidem, s. 137.

54 Ibidem, s. 116-117.

55 Ibidem, s. 136.

56 Ibidem, s. 115. 
Przykładu kolizji wartości i konieczności ważenia racji między nimi dostarcza również problematyka aborcji. Zdaniem A. Zolla w zagadnieniu tym ogniskuje się kolizja między dwoma dobrami: życiem dziecka i prawem kobiety ${ }^{57}$. Innego przykładu sytuacji konfliktu dostarcza wyrok Trybunału Konstytucyjnego w sprawie reform Balcerowicza. Jak zauważa ceniony prawnik, z formalnego punktu widzenia były podstawy, żeby uznać - ze względu na wsteczne działanie prawa - ustawy dokonujące zmian za niekonstytucyjne ${ }^{58}$. Niektóre z ustaw składających się na plan Balcerowicza zostały bowiem uchwalone przez Sejm w 1990 roku, a jednocześnie były one elementem budżetu zaproponowanego w 1989 roku. Mimo istniejących wątpliwości co do obowiązywania tych ustaw Trybunał Konstytucyjny, odwołując się do racji ekonomicznych i gospodarczych, nie dopatrzył się wadliwości tych aktów. Odmienne rozstrzygnięcie oznaczałoby wstrzymanie reform określanych planem Balcerowicza.

Innego aspektu tak rozumianej polityczności — jako wyboru określonych wartości — dostarcza proces legislacyjny. Jak odnotowuje A. Zoll:

Trudno też sobie wyobrazić stanowienie prawa bez pewnej koncepcji politycznej. Trzeba przyjąć i rozumieć, że program polityczny, który z reguły ogłaszany jest w exposé premiera, to nic innego, jak program legislacyjny rządu. Jeśli rząd planuje coś zrobić, to właśnie w ten sposób, że coś ureguluje, stworzy podstawy i ramy prawne do przewidywanych zmian ${ }^{59}$.

Jeśli trafnie odczytuję wypowiedzi krakowskiego badacza, to można z nich odczytać dwa ujęcia polityczności. Pierwsze z nich koncentruje się na układaniu relacji między różnymi ośrodkami władzy. W tym ujęciu, mówiąc o działaniach politycznych, autor ma na uwadze między innymi próbę wywierania wpływu przez władzę wykonawczą na władzę sądowniczą. Z kolei drugie myślenie o polityczności dotyczy wyboru określonej ideologii w procesie decyzyjnym przez poszczególne ośrodki władzy publicznej. O tak rozumianej polityczności można mówić zarówno na poziomie tworzenia prawa, jak i jego stosowania ${ }^{60}$.

W debacie o polityczności obecne jest także pytanie, czym jest prawo i jak jest ono legitymizowane. $Z$ jednej strony, wyróżnić można stanowisko, zgodnie z którym prawo powinno być podporządkowane woli politycznej, z drugiej zaś, obecny jest pogląd eksponujący tezę, że to prawo wyznacza granice polityki ${ }^{61}$.

Linia argumentacyjna pierwszej z wymienionych narracji podkreśla przewage woli narodu czy też opinii publicznej nad prawem. W ujęciu tym prawo jest narzędziem w rękach suwerena. $Z$ kolei drugie stanowisko nastawione jest na przedstawianie prawa jako czynnika ograniczającego konstytucyjne organy władzy. W ujęciu tym suwerenem jest prawo. Według A. Zolla przykładu prymatu polityki nad pra-

\footnotetext{
57 Ibidem, s. 253.

58 Ibidem, s. 130.

59 Ibidem, s. 306

60 Ibidem, s. 307

61 Ibidem, s. 165.
} 
wem dostarczają sytuacje, w których przyjmuje się rozwiązania legislacyjne uznające wsteczne działanie prawa albo wydłużanie okresu przedawnienia ${ }^{62}$. W tych przypadkach dochodzi do odejścia od podstawowych zasad prawa, które uzasadnia się zapotrzebowaniem społecznym, wolą opinii publicznej odczytywaną przez polityków ${ }^{63}$.

\section{POLITYCZNOŚĆ W PRAKTYCE ORZECZNICZEJ W ROZMOWIE Z ANDRZEJEM WRÓBLEM}

Jeśli trafnie odczytuję wypowiedzi Andrzeja Wróbla, to można je odnieść do dwóch ujęć polityczności, wyróżnionych już wcześniej. W pierwszym z nich mowa o polityczności na oznaczenie presji, jaka może być wywierana przez władzę wykonawczą na działalność sędziowską i trybunalską ${ }^{64}$. $Z$ tego powodu autor przywiązuje dużą uwagę do zasady trójpodziału władzy jako formalnego zabezpieczenia niezależności władzy sędziowskiej względem dwóch pozostałych ośrodków władzy. Jak odnotowuje A. Wróbel:

Za zasadą trójpodziału władz stoją nie tylko przepisy Konstytucji z 1997 roku i utrwalona praktyka konstytucyjna, lecz także wiekowa tradycja filozoficzno-polityczna, której w żaden sposób nie można ignorować ${ }^{65}$.

O pragmatycznie rozumianej polityczności można także mówić w kontekście wyboru sędziów do Trybunału Konstytucyjnego ${ }^{66}$. Zdaniem A. Wróbla tego rodzaju relacja nie przekłada się (a przynajmniej nie powinna) na kierowanie się w praktyce orzeczniczej racjami danej partii politycznej ${ }^{67}$. Głoszony w tym znaczeniu postulat apolityczności sędziów nie oznacza jednak apolityczności praktyki orzeczniczej ${ }^{68}$.

W drugim z ujęć polityczność to wybór określonej ideologii, zbioru poglądów na sposób funkcjonowania podstawowych organów władzy w państwie. W obrębie takiego stanowiska A. Wróbel wskazuje na dwa rozwiązania, które ukierunkowane są na polityczność w ujęciu: (1) Carla Schmitta: wróg-przyjaciel oraz (2) Arystotelesa: zarządzanie państwem w celu realizacji ważnych dla społeczeństwa celów ${ }^{69}$. Badacz w swoich rozważaniach opowiada się za perspektywą, która

62 Ibidem, s. 174.

${ }^{63}$ Innego przykładu traktowania prawa jako narzędzia w celu realizacji celów politycznych dostarcza problematyka karania, a dokładniej zaostrzanie wymiaru kary; zob. ibidem, s. 175.

${ }^{64}$ Andrzej Wróbel zauważa: ,panuje przekonanie, że sędzia czuje się związany z opcją polityczną, która go poparła, najdłużej przez rok, a potem zapomina o swoim rodowodzie »politycznym «" - K. Sobczak, A. Wróbel, op. cit., s. 29. Por. D. Kennedy, The hermeneutic of suspicion in contemporary American legal thought, „Law and Critique” 25, 2014, s. $114 \mathrm{n}$.

${ }^{65}$ K. Sobczak, A. Wróbel, op. cit., s. 23.

66 Ibidem s. 28.

67 Ibidem, s. 26.

68 Ibidem, s. 206-207.

69 Ibidem, s. 27. 
jest utożsamiana z Arystotelesem, a także propozycjami Hannah Arendt. Umocowania tej wizji A. Wróbel upatruje między innymi w zapisach konstytucyjnych:

To niezwykle istotne, że konstytucja nie jest efektem dominacji jednej koncepcji filozoficzno-politycznej nad innymi, tylko zazwyczaj w większości państw demokratycznych jest wyrazem kompromisu, czyli rodzaju umowy społecznej, jaką zawierają ze sobą należący do różnych opcji politycznych rządzący i rządzeni ${ }^{70}$.

Jeśli trafnie rozumiem zamysł A. Wróbla, to działalność sędziego powinna być ukierunkowana na realizowanie tak rozumianej polityki. Przykładu takiego zaangażowania dostarczają prawa socjalne. Jak podkreśla interesujący nas autor:

Prawa socjalne nie są przy tym kategorią wewnętrznie jednolitą, obok bowiem praw typowo socjalnych, jak prawo do zabezpieczenia czy ubezpieczenia socjalnego i prawo do pomocy społecznej, czy praw osób niepełnosprawnych, zalicza się do nich także prawa pracownicze, ale również prawo do ochrony zdrowia czy prawo do nauki ${ }^{71}$.

Konstytucjonalizacja praw socjalnych jest wyrazem polityczności rozumianej jako wybór określonych wartości, ich preferencji w przestrzeni publicznej ${ }^{72}$. Jak zauważa ceniony prawnik, zapewnienie minimum socjalnego i życiowego wyznacza granicę ingerencji ustawodawcy ${ }^{73}$. Jeśli zatem projektowane przepisy ustawy wkraczałyby w sferę prawa minimalnego, to można na tej podstawie uznać ich niekonstytucyjność ${ }^{74}$. Zdaniem A. Wróbla linię argumentacyjną na rzecz prezentowanego stanowiska można budować, opierając się na trzech racjach: godności człowieka, zasadzie sprawiedliwości społecznej i modelu solidarnościowym ${ }^{75}$. $\mathrm{Na}$ ich podstawie nie należy ograniczać praw socjalnych nawet w sytuacji pogorszenia się koniunktury gospodarczej ${ }^{76}$.

Ale niezależnie od poziomu rozwoju gospodarczego państwa, jeżeli standard minimum socjalnego czy życiowego budujemy na godności, to pewien poziom pomocy społecznej musi być zagwarantowany, żeby człowiek mógł przeżyć. [...] I to jest podstawowa wskazówka dla kształtowania pomocy społecznej w państwie ${ }^{77}$.

A. Wróbel, uzasadniając rygorystyczną ochronę praw związanych z zapewnieniem minimum socjalnego i życiowego, wskazuje, że stanowią one istotę praw

70 Ibidem, s. 17.

71 Ibidem, s. 217.

72 Andrzej Wróbel zauważa: „Celem konstytucjonalizacji praw socjalnych jest zapewnienie bezpieczeństwa prawnego osobom wymagającym wsparcia oraz sprawiedliwej i równej dystrybucji ograniczonych dóbr, czego nie zapewnia gospodarka rynkowa. Ważną funkcją praw socjalnych jest ochrona osób wykluczonych z życia społecznego, politycznego i gospodarczego wspólnoty" — ibidem, s. 209.
73 Ibidem, s. 213.
${ }^{74}$ Ibidem, s. 223-224.
75 Ibidem, s. 215-216.
76 Ibidem, s. 225.
77 Ibidem, s. 213. 
socjalnych $^{78}$. O ile $\mathrm{w}$ wypadku minimum życiowego mówimy o zapewnieniu jednostce bezpieczeństwa egzystencjalnego, o tyle w odniesieniu do minimum socjalnego można wskazać na prawa, których celem jest zagwarantowanie uczestnictwa w życiu społeczno-kulturowym. W tym zakresie celem praw socjalnych jest aktywizacja społeczna i polityczna jednostki, zapobiegnięcie sytuacji, która spowodowałaby pozostawienie człowieka na marginesie życia społecznego ${ }^{79}$. Przykładem tak rozumianych praw socjalnych nie jest wynagrodzenie sędziów. $Z$ tego powodu ceniony prawnik stwierdza, że zamrożenie płac sędziowskich, z jakim mieliśmy do czynienia kilka lat temu, nie narusza podstawowych praw socjalnych osób wykonujących tę profesję ${ }^{80}$.

A. Wróbel, wyjaśniając znaczenie praw socjalnych, posługuje się metaforą kręgów:

W orzecznictwie Trybunału Konstytucyjnego dotyczącym praw socjalnych traktujemy je jako zbiór takich kręgów, z których ten najmniejszy znajdujący się w środku jest istotą tego prawa, która jest określona w Konstytucji, a te kolejne kręgi zewnętrzne są już sferą pozostawioną do decyzji ustawodawcy. Inaczej mówiąc, ten wewnętrzny krąg, który Trybunał definiuje w ramach interpretacji Konstytucji, jest poza kompetencjami innych władz ${ }^{81}$.

W praktyce orzeczniczej Trybunału Konstytucyjnego wyróżnia się dwa typy praw socjalnych — pierwszy z nich rozumiany jako prawa podmiotowe, a drugi jako normy programowe ${ }^{82}$. W pewnym uproszeniu można powiedzieć, że kręgi wewnętrzne stanowią prawa podmiotowe, $\mathrm{z}$ kolei te skrajnie zewnętrzne - normy programowe. Przykładem prawa podmiotowego jest prawo do zabezpieczenia społecznego, a normy programowej — sprzyjanie zaspokajaniu potrzeb mieszkaniowych. Różnica między nimi polega na rodzaju obowiązku, jaki rodzi to prawo po stronie państwa. W przypadku naruszenia praw podmiotowych jednostka ma prawo dochodzić swoich uprawnień przed sądami. Podstawą roszczenia jest niewywiązanie się państwa z konstytucyjnych praw. Natomiast niespełnienie norm programowych nie tworzy przesłanki uzasadniającej takie roszczenie. Można zatem powiedzieć, że prawa socjalne mają różny stopień gwarancji ${ }^{83}$.

78 Ibidem, s. 225 n.

79 Ibidem, s. 213-214. W innym miejscu Andrzej Wróbel stwierdza: „Według mnie minimum życiowe oznacza minimum dóbr niezbędnych do przeżycia. Przy minimum socjalnym zaś wchodzą już w grę różne konteksty. Przy minimum życiowym obowiązują kryteria biologiczne, a przy socjalnym — także społeczne" — ibidem, s. 232-233.

${ }^{80}$ Wyrok TK z dnia 12 grudnia 2012 roku, sygn. K 1/12, Dz.U. z 2012 r. poz. 1510; K. Sobczak, A. Wróbel, op. cit., s. 226.

81 K. Sobczak, A. Wróbel, op. cit., s. 234.

${ }^{82}$ Ibidem, s. 236.

83 Warto przytoczyć słowa Andrzeja Wróbla: „musimy na prawa socjalne patrzeć bardziej jako na prawa niż jako na normy wyznaczające jedynie cele. Trzeba je traktować jako reguły wiążące państwo. Jeżeli bowiem uznamy, że jest to norma programowa, to dla obywatela jeszcze nic konkretnego z tego nie wynika. [...] On nie ma z tego tytułu żadnych roszczeń. Tylko państwo ma 
Innych przykładów zaangażowania politycznego dostarczają orzeczenia dotyczące wolności religii i sumienia. Jednym z nich jest sprawa uboju rytualnego, rozpatrywana przez Trybunał Konstytucyjny ${ }^{84}$. Przypomnijmy, że Trybunał uznał, że zakaz uboju rytualnego na potrzeby gmin żydowskich jest niekonstytucyjny. Uzasadniając to stanowisko, stwierdzono, że zakaz uboju rytualnego narusza wolność kultu religijnego i prawa mniejszości etnicznych do pielęgnowania tradycji ${ }^{85}$. $W$ rozstrzygnięciu tym poddawano ocenie rytuał religijny i przemoc wobec zwierząt z jednej strony, a z drugiej — wolność religijną. W tle tego sporu pojawiało się również pytanie o wolność gospodarczą. Innej jeszcze ilustracji sporu o wartości dostarczają orzeczenia dotyczące prawa wyrażania i ochrony uczuć religijnych a swobody twórczości artystycznej ${ }^{86}$. Przykładem takiego konfliktu jest sprawa piosenkarki Doroty Rabczewskiej, która w jednym z wywiadów określiła autorów Biblii jako „naprutych winem i palących jakiejś zioła”. W sprawie skazania piosenkarki przez sąd wypowiedział się Trybunał Konstytucyjny, uznając, że doszło do naruszenia uczuć religijnych. Kluczowym argumentem było uznanie, że „Mamy Konstytucję, która wyraźnie chroni wolność religijną, a więc nie można przykładać znieważenia uczuć religijnych do swobody wyrażania poglądów"87.

$\mathrm{Z}$ przedstawionych wypowiedzi A. Wróbla można wyprowadzić stanowisko, zgodnie z którym autor broni tezy o apolityczności sędziów i polityczności w praktyce orzeczniczej. Wpisuje się ono w przedstawianą już tezę, w której upartyjnienie działalności sędziowskiej jest czymś innym aniżeli polityczność rozumiana jako konieczność wyboru określonych wartości w sytuacji konfliktu między nimi. $\mathrm{Z}$ wyborem tym, jak zauważa prawnik, mamy do czynienia na poziomie zarówno stosowania prawa, jak i jego tworzenia.

\section{WNIOSKI}

W prezentowanym artykule, na podstawie rozmów z Ewą Łętowską, Andrzejem Zollem i Andrzejem Wróblem, które przeprowadził Krzysztof Sobczak, starałem się dokonać weryfikacji dwóch hipotez. Pierwsza z nich zakłada, że tematyka polityczności jest obecna w polskiej debacie o państwie prawa po 1989 roku. Wypowiedzi wymienionych autorów można moim zdaniem przyporządkować do pojęcia polityczności w ujęciu pragmatycznym i apragmatycznym. Do pragmatycznie rozumianej polityczności można odnieść wypowiedzi eksponujące:

\footnotetext{
obowiązki, które powinno zrealizować. A więc nazwanie pewnych praw socjalnych normami programowymi deklasuje je, a nawet dekonstytucjonalizuje" - ibidem, s. 248.

${ }^{84}$ Wyrok TK z dnia 10 grudnia 2014 roku, sygn. K 52/13, Dz.U. z 2014 r. poz. 1794.

85 K. Sobczak, A. Wróbel, op. cit., s. 257.

86 Ibidem, s. 261. Zob. wyrok TK z dnia 6 października 2015 roku, sygn. SK 54/13, Dz.U. z 2015 r. poz. 1632.

${ }^{87}$ K. Sobczak, A. Wróbel, op. cit., s. 267.
} 
1. znaczenie zasady trójpodziału władzy, zarówno z punktu widzenia społecznego, jak i instytucjonalnego;

2. sytuacje naruszania tej zasady i w konsekwencji osłabiania niezależności sądownictwa względem dwóch pozostałych ośrodków władzy.

Z kolei do apragmatycznego ujęcia polityczności można przyporządkować wypowiedzi, które zwracają uwagę na sytuację konfliktu wartości w praktyce orzeczniczej. Odpowiedź na nią może być różna, co odnotowuje E. Łętowska, wskazując na postawę Piłata.

Drugie z zadań koncentrowało się na rozważeniu hipotezy, zgodnie z którą myślenie o polityczności, jakie wyłania się z prezentowanej debaty, bliższe jest polityce sceptycyzmu. Na rzecz takiego stanowiska przemawia rekomendowana przez omawianych prawników zasada trójpodziału władzy. Jest ona odpowiedzią na potencjalną podejrzliwość wobec działalności władzy publicznej. Jak odnotowuje Adam Shinar, praktyka stanowienia prawa przeciwko rządom prawa może dotyczyć każdej z trzech władz ${ }^{88}$. Dlatego też celem rządów prawa jest budowanie i ochrona systemu wzajemnej kontroli. W wizji tej prawo jest suwerenem, które niczym łańcuch ogranicza władze publiczne. Takie uznanie wymaga zachowania odpowiedniej postawy wobec prawa ${ }^{89}$. To zdaje się mieć na uwadze Artur Kozak, przestrzegając przed konsekwencjami podważania zasad podstawności prawa:

Odnosi się wrażenie, że wielu polityków postanowiło wraz z masami podważyć ład instytucjonalny współczesnego społeczeństwa, w przekonaniu, iż w ten sposób uda im się ocalić przynajmniej to, co uważają za jego najważniejszy element — demokratyczną politykę. Ale zachowują się oni jak rozbitek, który w panice próbuje ratować własne życie, używając jako oparcia i wpychając pod wodę swego towarzysza. Głębia pod nimi jest wystarczająco duża, by pochłonąc ich wszystkich ${ }^{90}$.

\section{THE POLITICAL IN ADJUDICATION: CONVERSATIONS ABOUT THE RULE OF LAW WITH EWA ŁECTOWSKA, ANDRZEJ ZOLL, ANDRZEJ WRÓBEL}

\section{Summary}

In the presented article I tried to show the presence of political issues in the Polish debate on judicial practice. In pursuit of this goal, first of all, I focus on the conversations with Ewa Łętowska, Andrzej Zoll, and Andrzej Wróbel, conducted by Krzysztof Sobczak. Then, I answer the question of

88 A. Shinar, op. cit., zwł. s. 149-150. Podobnie P. van Lochem, op. cit., s. 98 n.

89 A. Dyrda, Zasada rząów prawa: zasada z zasady sporna?, [w:] Filozoficzne i teoretyczne zagadnienia demokratycznego państwa prawa, red. M. Andruszkiewicz, A. Breczko, S. Oliwniak, Białystok 2015, s. 211, przyp. 7.

90 A. Kozak, Kryzys podstawności prawa, [w:] System prawny a porzadek prawny, red. O. Bogucki, S. Czepita, Szczecin 2008, s. 57. 
how understood politics emerges through these conversations. In carrying out this task, I refer to the dictionary of terms proposed by Michael Oakeshott.

Keywords: the political, role of judge, the rule of law, judicial practice

\section{BIBLIOGRAFIA}

Bator A., Polityczne interpretacje analitycznej teorii prawa, [w:] Integracja zewnętrzna i wewnętrzna nauk prawnych. Cz. 1, red. M. Zirk-Sadowski, B. Wojciechowski, T. Bekrycht, Łódź 2014.

Dyrda A., Zasada rządów prawa: zasada z zasady sporna?, [w:] Filozoficzne i teoretyczne zagadnienia demokratycznego państwa prawa, red. M. Andruszkiewicz, A. Breczko, S. Oliwniak, Białystok 2015.

Gadamer H.G., Cóż to jest prawda?, [w:] idem, Rozum, stowo, dzieje. Szkice wybrane, wyb., oprac. i wstęp K. Michalski, przeł. M. Łukasiewicz, K. Michalski, Warszawa 1979.

Gersdorf M., Sobczak K., Czasem trzeba powiedzieć „nie” — Małgorzata Gersdorf w rozmowie z Krzysztofem Sobczakiem o swojej walce o niezależne sądy, Warszawa 2020.

Gudowski J., Sobczak K., Państwo prawa to niezależne sądy. Jacek Gudowski w rozmowie z Krzysztofem Sobczakiem, Warszawa 2018.

Kennedy D., The hermeneutic of suspicion in contemporary American legal thought, „Law and Critique" 25, 2014.

Kozak A., Kryzys podstawności prawa, [w:] System prawny a porzadek prawny, red. O. Bogucki, S. Czepita, Szczecin 2008.

Lochem P. van, Legislation against the rule of law - an introduction, „The Theory and Practice of Legislation" 5, 2017.

Łętowska E., Dekalog sędziego. Dwadzieścia lat później, [w:] Konstytucja, praworzadność, władza sadownicza. Aktualne problemy trzeciej władzy w Polsce, red. Ł. Bojarski, K. Grajewski, J. Kremer, G. Ott, W. Żurek, Warszawa 2019.

Łętowska E., Sobczak K., Rzeźbienie państwa prawa. 20 lat póżniej. Ewa Łętowska w rozmowie z Krzysztofem Sobczakiem, Warszawa 2012.

Mańko R., Nauki prawne wobec problemu polityczności: zagadnienia wybrane z perspektywy jurysprudencji krytycznej, „Archiwum z Filozofii Prawa i Filozofii Społecznej” 2018, nr 3.

Mańko R., W stronę krytycznej filozofii orzekania. Polityczność, etyka, legitymizacja, Łódź 2018.

Oakeshott M., Losy sceptycyzmu. Rozproszenie władzy a tradycje angielskiej polityki, przeł. S. Stecko, „Nowa Res Publica” 2002, nr 9.

Oakeshott M., Polityka wiary i polityka sceptycyzmu, przeł. M. Szczubiałka, red. T. Fuller, Warszawa 2019.

Polakowski M., Sceptycyzm w polityce. Studium myśli politycznej Michaela Oakeshota, Płock 2017.

Rzepliński A., Sobczak K., Stużą rządom dobrego prawa. Andrzej Rzepliński w rozmowie z Krzysztofem Sobczakiem, Warszawa 2015.

Schmitt C., Pojęcie polityczności, [w:] idem, Teologia polityczna i inne pisma, przeł. M.A. Cichocki, Kraków 2000.

Shinar A., One rule to rule them all? Rules of law against the rule of law, „The Theory and Practice of Legislation" 5, 2017.

Sobczak K., Wróbel A., Warto chronić państwo prawa. Andrzej Wróbel w rozmowie z Krzysztofem Sobczakiem, Warszawa 2017.

Sobczak K., Zoll A., Państwo prawa jeszcze w budowie. Andrzej Zoll w rozmowie z Krzysztofem Sobczakiem, Warszawa 2013.

Stambulski M., Polityczność jako etyka polityczna prawa, [w:] Aksjologiczny wymiar prawa, red. M. Dudek, M. Stępień, Kraków 2015. 
Stambulski M., Polityczność w polskiej analitycznej teorii prawa. Zarys problematyki, „Archiwum z Filozofii Prawa i Filozofii Społecznej” 2018, nr 3.

Śpiewak P., Granice polityki, [w:] M. Oakeshott, Wieża Babel i inne eseje, przeł. A. Lipszyc, Ł. Sommer, M. Szczubiałka, Warszawa 1999.

Śpiewak P., W stronę wspólnego dobra, Warszawa 1998.

Weber M., Gospodarka i społeczeństwo. Zarys socjologii rozumiejącej, przeł. i wstęp D. Lachowska, Warszawa 2002.

Wolmarans F.G., A 'conversation' concerning political understanding: Bacon contra Augustine or the 'politics of faith' contra the 'politics of scepticism', „Politikon: South African Journal of Political Studies" 29, 2002. 